\title{
PERJANJIAN INTERNASIONAL
}

\section{SEBAGAI INSTRUMEN REKAYASA GLOBAL DAN HARMONISASI \\ PRINSIP-PRINSIP HUKUM LINGKUNGAN}

\author{
Manuel Simbolon \\ SIADARI \& PARTNERS Law Firm
}

\begin{abstract}
ABSTRAK
Perjanjian internasional merupakan salah satu sumber hukum internasional yang sering digunakan. Dalam bidang lingkungan hidup, terdapat banyak perjanjian internasional yang telah dibuat untuk mengkoordinasikan kebijakan negara-negara di bidang lingkungan hidup. Perjanjian internasional tersebut digunakan sebagai instrumen rekayasa global. Namun banyak di antara perjanjian internasional tersebut berkarakter soft law sehingga tidak dapat mengikat negara-negara dan mempengaruhi kebijakan nasionalnya di bidang lingkungan hidup.
\end{abstract}

Kata kunci: perjanjian internasional, soft law, hard law

\begin{abstract}
Treaty is one of the sources of international that frequently used. In the environmental field, there are many international agreements that have been made to coordinate the policies of countries in the environmental field. The treaty is used as an instrument of global engineering. But many of the treaty are the soft law and therefore can not bind countries and influencing national policy in the environmental field.
\end{abstract}

Keywords: treaty, soft law, hard law

\section{A. PENDAHULUAN}

Globalisasi adalah topik yang terlampau hangat untuk dikaji dewasa ini. Bukan hanya karena dia menjadi fenomena kekinian, tetapi karena kompleksitas dan dampaknya yang (seolah) tanpa batas. Wajah dunia dalam era globalisasi adalah dunia yang mengenali dirinya dengan cara tidak mengenalnya. Wajah yang semakin murung namun lebih bersemangat, semakin sedih namun lebih 
menggeliat, semakin tak berdaya namun lebih beringas. Globalisasi adalah sebuah gambaran dunia yang semakin menua sedang berkeras meremajakan dirinya.

Dalam bukunya yang berjudul "The World is Flat", Thomas Friedman berpendapat bahwa globalisasi telah membuat dunia menjadi lebih datar.

${ }^{1}$ Datar yang dimaksud Friedman adalah kondisi yang membuat dunia berada dalam titik yang semakin setara. Polarisasi kekuatan dunia lenyap dan menyebabkan tidak ada lagi kiblat kekuatan dunia. Jauh daripada itu globalisasi yang menyebabkan kedataran dunia mengakibatkan terhubungnya negara-negara satu sama lain.

Sebagaimana ditunjukkan oleh akar katanya, globalisasi melibatkan relasirelasi global sebagai skala ruangnya, dan berkaitan erat dengan perekonomian. Paul Hirst dan Graham Thompson,seperti yang dikutip oleh Anthony Giddens menyatakan bahwa: “...sebuah perekonomian yang benar-benar global dinyatakan telah muncul, atau sedang dalam proses kemunculan, perekonomian nasional yang khusus dan, karena itu, strategi-strategi domestik perekonomian nasional semakin tidak relevan." 2

Dunia yang semakin datar telah membuat perdagangan menjadi bebas. Bebas yang dimaksud adalah terbukanya peluang bagi semua pihak untuk melakukan perdagangan, entah itu negara antar negara, korporasi, ataupun individu. Salah satu pendorong besar yang membuka peluang tersebut adalah kemajuan teknologi. Teknologi yang terus berkembang pesat pasca revolusi industri membuat dunia menjadi berubah hanya dalam hitungan beberapa abad saja.

Globalisasi juga menunjukkan wajah murung dunia. Isu lingkungan, pemanasan global dan perubahan iklim seakan menjadi konsekuensi dari segala macam bentuk kemajuan teknologi dan aktivitas ekonomi dunia. Dampak

\footnotetext{
1 Thomas L. Friedman, The World is Flat : Sejarah Singkat Abad ke-21, Cet. I, Jakarta: Dian Rakyat, 2006, hlm. 8.

${ }^{2}$ Paul Hirst dan Graham Thompson, dalam Anthony Giddens, The Third Way: The Renewal of Social Democracy, Jalan Ketiga: Pembaruan Demokrasi Sosial, Terjemahan oleh Ketut Arya Mahardika, Jakarta: Gramedia Pustaka Utama, 1999, hlm. 33. Namun Giddens menyatakan bahwa Klaim Hirst dan Thompson ini bisa mudah ditentang. Giddens membandingkannya dengan fenomena perdagangan regional seperti yang terjadi pada negara - negara Uni Eropa, dan negara negara Amerika Utara, dan menganggap perdagangan jenis ini tidak sepenuhnya mendukung "perekonomian yang sepenuhnya global".
} 
terhadap lingkungan yang telah diciptakan oleh globalisasi bukan hanya menjadi monopoli negara maju, namun juga turut mengikutsertakan negara - negara dunia ketiga. Kemajuan teknologi dan aktivitas ekonomi dalam skala besar yang telah mendorong industrialisasi memang memberikan dampak positif bagi perkembangan perekonomian negara - negara dunia ketiga, namun industrialisasi tersebut juga kemudian memberikan dampak yang jauh lebih buruk.

Pertumbuhan ekonomi telah mendorong terjadinya lonjakan penduduk, dan dengan demikian turut pula mendorong pertumbuhan konsumsi pangan, kebutuhan hidup, dan energi yang tinggi. Kebutuhan akan konsumsi pangan yang melonjak jelas akan mendorong industrialisasi pertanian. Industrialisasi pertanian membutuhkan lahan yang cukup luas, sehingga akan mendorong terjadinya deforestrasi untuk kebutuhan lahan. Disisi lain kebutuhan akan energi yang sampai dengan saat ini masih bertumpu pada minyak bumi akan mengakibatkan semakin menipisnya cadangan minyak bumi.

Dari situasi - situasi tersebut maka timbul pertanyaan, ketika masalahmasalah tersebut terjadi dalam skala negara maka penyelesaiannya dapat dilakukan dengan perekayasaan kondisi melalui hukum nasional, tetapi ketika masalah tersebut adalah masalah global bagaimanakah hukum dapat menjawab masalah-masalah global tersebut? Sementara negara masih memegang peranan dalam mempengaruhi perubahan global. Tatanan global yang dibentuk tentu diarahkan kepada ruang lingkup negara, namun hukum internasional kemudian akan berbenturan dengan kedaulatan negara pada saat hukum internasional menjadi instrumen rekayasa global dalam menjawab permasalahan-permasalahan global tersebut. Hal tersebut tidak terlepas dari natur hukum internasional yang hanya bersifat koordinatif, dan hukum nasional bukanlah subordinat dari hukum internasional.

Untuk menggunakan hukum internasional sebagai instrumen rekayasa global, maka haruslah dimulai dengan sukarela oleh negara-negara yang merasa memerlukan suatu aksi nyata dan memformulasikannya dalam suatu perjanjian internasional. Perjanjian internasional dalam situasi global kontemporer memiliki 
peran yang lebih signifikan. Selain sebagai sumber hukum formil, perjanjian juga menjadi instrumen untuk meneguhkan hak dan kewajiban antar negara.

Perjanjian internasional sebagai sumber hukum internasional dapat berlaku secara efektif ketika negara meratifikasinya. Ratifikasi perjanjian internasional oleh suatu negara bukan hanya didasari oleh sifat kesukarelaan suatu negara tetapi juga kewajiban yang diberikan untuk meratifikasi berdasarkan perjanjian tersebut, dalam hal inilah perjanjian internasional memiliki karakteristik sebagai hard law. Namun tidak seluruhnya perjanjian internasional memberikan kewajiban yang tegas dan pasti untuk meratifikasinya dalam hukum nasional. Perjanjian internasional dalam bentuk ini hanya menjadi prinsip belaka dalam tatanan masyarakat internasional. Dalam hal inilah perjanjian internasional memiliki karakteristik sebagai soft law.

Di sinilah urgensi prinsip-prinsip dalam hard law dan soft law diharmonisasikan ke dalam hukum nasional. Oleh karena itu tulisan ini akan mengkaji harmonisasi prinsip-prinsip hukum yang terkandung dalam perjanjian internasional ke dalam hukum nasional. Penulis juga akan mengkaji sejauh mana pengaruh perjanjian internasional tersebut, dengan karakternya yang dualistis, melalui proses harmonisasi, terhadap terciptanya tatanan global di bidang lingkungan hidup.

\section{B. PERKEMBANGAN PERJANJIAN INTERNASIONAL DI BIDANG LINGKUNGAN HIDUP SEBAGAI INSTRUMEN REKAYASA GLOBAL}

Kesadaran tentang perlunya penanganan masalah lingkungan hidup melalui instrumen hukum dimulai di tahun 1960an dan 1970an. Namun awalnya respon tersebut dimulai terbatas pada level nasional sebagai respon terhadap pencemaran air dan udara yang mulai terasa karena industrialisasi hingga negara berkembang pasca Perang Dunia II. Kemudian muncul kesadaran bahwa masalah tersebut tidak dapat sekedar ditangani dalam level nasional karena pencemaran lingkungan, terutama air dan udara, mengakibatkan pengaruh yang bersifat trans nasional. Hal inilah yang kemudian mendorong munculnya gelombang pertama dari apa yang 
disebut sebagai multilateral environmental agreements (MEAs) atau perjanjian multilateral di bidang lingkungan hidup. ${ }^{3}$

Awalnya dimulai di tahun 1962 ketika Majelis Umum Perserikatan BangsaBangsa (PBB) menyetujui Resolusi 1831 tentang Pembangunan Ekonomi dan Konservasi Alam yang menganggap sumber daya alam sebagai unsur penting dalam pembangunan ekonomi bagi setiap negara dan dapat memberikan keuntungan bagi rakyatnya. Resolusi ini juga mengungkapkan keraguan tentang pembangunan di negara berkembang yang dapat membahayakan lingkungan dan sumber daya alam, termasuk flora dan fauna. Kekhawatiran ini kemudian mendorong UNESCO untuk mendorong legislasi di masing-masing negara sehingga dapat mengatur pelestarian dan penggunaan sumber daya alam secara rasional. $^{4}$

PBB selanjutnya menjadi pihak yang mendorong aktif terbentuknya perjanjian-perjanjian multilateral di bidang lingkungan hidup. Usaha PBB untuk mendorong penanganan isu lingkungan hidup secara komprehensif dalam skala global kemudian dilanjutkan dalam UN Conference on the Human Environment yang diselenggarakan di Stockholm tahun 1972. Konferensi tersebut menghasilkan Stockholm Declaration on the Human Environment yang kemudian mendorong dimulainya salah satu program PBB di bidang lingkungan hidup dan berpusat di Nairobi, yaitu UN Environment Program (UNEP). Deklarasi Stockholm menghasilkan beberapa prinsip penyelamatan lingkungan hidup, penggunaan sumber daya terbarukan, perlindungan flora dan fauna, pembatasan pelepasan bahan berbahaya beracun, pencegahan pencemaran laut dan hubungan antara perlindungan lingkungan hidup dan perkembangan ekonomi. Prinsipprinsip tersebut terkandung dalam dua puluh enam (26) prinsip yang dihasilkan dalam Deklarasi Stockholm.

\footnotetext{
${ }^{3}$ Mark Drumbl, Actors and Law-Making in International Environmental Law, Washington \& Lee Public

Legal Studies Research Paper Series, http://ssrn.com/abstract=1022363, diakses pada tanggal 25 April 2012.

${ }^{4}$ Nico Schrijver, Sovereignty over Natural Resources, Cambridge: Cambridge University Press, 1997, hlm. 121.
} 
Di tahun 1982 Majelis Umum PBB menyetujui Piagam Dunia untuk Alam atau World Charter for Nature. Piagam tersebut berdasarkan pada prinsip perlindungan lingkungan dan sumber daya yang ada. Di tahun 1983, PBB membentuk World Commission on the Environment and Development untuk meneliti isu-isu pembangunan dan perlindungan lingkungan hidup. Komisi tersebut menghasilkan Brundtland Report, dipublikasikan dengan tajuk Our Common Future, yang kemudian disetujui oleh Majelis Umum pada tahun 1987. Laporan tersebut merekomendasikan suatu pendekatan holistik berdasarkan prinsip pembangunan berkelanjutan. ${ }^{5}$

UN Conference on Environment and Development untuk kali kedua diselenggarakan di Rio de Janeiro pada tahun 1992. Dokumen penting yang disepakati dalam konferensi ini adalah Deklarasi Rio tentang Lingkungan Hidup dan Pembangunan, dan Agenda 21. Deklarasi Rio adalah suatu pernyataan prinsip-prinsip dan tujuan-tujuan yang ingin dicapai. Agenda 21 adalah suatu rencana aksi yang tidak mengikat dan fungsinya untuk mengarahkan negaranegara di semua aspek lingkungan hidup dan pembangunan, mencakup dimensi sosial dan ekonomi, konservasi dan manajemen sumber daya alam, penguatan peranan kelompok-kelompok utama. Konferensi ini juga juga menghasilkan Biodiversity Convention dan United Nations Framework Convention on Climate Change (UNFCCC). ${ }^{6}$

Selain perjanjian-perjanjian dalam lingkungan hidup yang sifatnya umum tersebut, terdapat pula perjanjian-perjanjian yang spesifik pada isu-isu khusus di bidang lingkungan hidup. Munculnya perjanjian-perjanjian internasional tersebut dapat dibagi ke dalam dua generasi. Generasi pertama adalah perjanjian-perjanjian yang fokus pada isu pencemaran air dan udara, konservasi alam liar, dan perlindungan terhadap habitat yang rentan. Generasi kedua adalah perjanjianperjanjian yang fokus kepada isu yang terkait implikasi gaya hidup dan perilaku ekonomi terhadap perkembangan lingkungan hidup.

\footnotetext{
5 Jane Stratton, International Environmental Law, dalam International Law, ed.Cathy Hammer, Sydney: Legal Information Access Centre, 2009, hlm.20.

${ }^{6}$ Ibid.
} 
Manuel Simbolon, Perjanjian Internasional sebagai Instrumen ...

Perbedaan isu antara dua generasi tersebut menunjukkan bahwa perkembangan perjanjian internasional pun mengalami perubahan paradigma dalam melihat kerusakan lingkungan hidup. Era 1960an dan 1970an memberi banyak perhatian pada isu pencemaran air dan udara karena pada saat itu industrialisasi sedang gencar-gencarnya dilakukan. Industrialisasi terjadi merata di negara-negara Utara maupun beberapa negara Selatan. Persaingan di era Perang Dingin pun turut mempengaruhi percepatan industrialisasi di negara-negara tersebut. Deklarasi Stockholm di tahun 1972 juga menyimpulkan bahwa negaranegara maju berkontribusi dalam pencemaran lingkungan karena industrialisasi, sedangkan negara-negara berkembang disebabkan justru karena kurangnya pembangunan.

Namun di dasawarsa selanjutnya, khususnya pasca-Perang Dingin, isu lingkungan hidup yang menjadi fokus perjanjian-perjanjian internasional lingkungan hidup bukan hanya pada dampak yang ditimbulkan industrialisasi secara langsung. Perkembangan telah berubah dan beberapa negara tidak lagi memasuki era produksi tetapi justru era konsumsi. Negara-negara Utara tidak lagi bertumpu pada industri-industri mainstream di dasawarsa sebelumnya. Negaranegara tersebut telah memasuki era industri jasa dan berkembangnya teknologi informasi yang memunculkan jenis industri baru yang sangat berbeda dari dasawarsa sebelumnya. Ketika negara-negara tersebut memasuki era konsumsi, terjadilah dikotomi antara industrialized countries dan industrializing countries.

Walaupun negara-negara Utara sudah meninggalkan era produksi oleh industri-industri tetapi masalah lingkungan hidup bukannya tidak berkurang. Pergeseran tersebut justru menimbulkan masalah yang lebih pelik. Modal-modal untuk industri telah dialihkan ke negara-negara berkembang dan negara berkembang pada akhirnya semakin berperan dalam pencemaran lingkungan akibat industrialisasi. Sementara di belahan dunia lainnya, perilaku konsumsi di negara-negara maju juga berpengaruh terhadap kualitas lingkungan hidup. Kemakmuran di negara-negara mengakibatkan tingginya konsumsi energi yang dibutuhkan. Konsumsi energi yang meningkat secara signifikan juga turut menyumbang pencemaran, khususnya pencemaran udara. Tingginya konsumsi di 
negara-negara maju terhadap consumer goods yang berbahan baku minyak sawit telah mendorong pembukaan lahan baru perkebunan kelapa sawit di negara berkembang. Pembukaan lahan baru tersebut secara langsung mendorong berkurangnya hutan-hutan yang menjadi paru-paru dunia. Pergeseran paradigma tersebut dapat dilihat dengan lebih berkembangnya isu pemanasan global dan perubahan iklim. Pasca UNFCCC dan Protokol Kyoto, negara maju diharuskan untuk menurunkan emisi gas rumah kaca 5\% di bawah emisi 1990. Kewajiban menurunkan emisi tersebut kemudian mendorong kerjasama secara patungan antar negara dalam hal perdagangan emisi. ${ }^{7}$

Dengan perkembangan tersebut tampaknya instrumen perjanjian internasional akan tetap memegang peranan penting dalam mempengaruhi kebijakan-kebijakan yang nantinya akan berakibat secara langsung ataupun tidak langsung terhadap lingkungan hidup. Oleh karena itu menjadi penting untuk mengetahui sejauhmana suatu perjanjian internasional, dalam konteks ini di bidang lingkungan hidup, dapat mengikat negara-negara yang menyepakati perjanjian-perjanjian tersebut. Karena jika suatu perjanjian internasional ternyata tidak dapat mengikat pihakpihak yang turut bersepakat dalam perjanjian tersebut, maka perjanjian internasional tersebut tidak dapat dikatakan memiliki fungsi rekayasa global. Hal ini didukung adanya konsensus keilmuan bahwa kerangka perlindungan lingkungan hidup pada tataran hukum internasional membutuhkan kejelasan status hukum pengaturannya. Keseluruhan komitmen dan langkah-langkah implementasi di bidang lingkungan hidup membutuhkan adanya dasar yuridis berupa legislasi secara formal. $^{8}$

\section{KARAKTERISTIK HARD LAW DAN SOFT LAW DALAM PERJANJIAN INTERNASIONAL}

Hard law dan soft law dalam perjanjian internasional dapat dibedakan dari berbagai variasi sudut pandang. Hard law, sebagai jenis yang ideal, meletakkan kewajiban yang mengikat secara hukum dan kewajiban tersebut dirumuskan

7 Suparto Wijoyo, Refleksi Matarantai Pengaturan Hukum Pengelolaan Lingkungan secara Terpadu, Surabaya: Airlangga University Press, 2005, hlm. 643.

${ }^{8}$ Ibid, hlm. 644. 
secara jelas, serta mendelegasikan kewenangan untuk menginterpretasikan dan mengimplementasikan perjanjian tersebut. Sebaliknya, soft law tidak meletakkan kewajiban dan wewenang yang demikian bagi para pihak yang terkait dalam perjanjian internasional tersebut. Karena perjanjian internasional hampir tanpa kecuali menunjukkan kelemahan-kelemahan dalam beberapa aspek, perjanjian internasional dapat dilihat dari ada tidaknya karakteristik hard law atau soft law. ${ }^{9}$

Analisis terhadap hard law dan soft law tersebut, jika mengacu pada pendapat Abbott et.al, menempatkan tiga aspek penting dalam melihat karakteristik hard law dan soft law. Pertama, aspek kewajiban yang diberikan oleh perjanjian tersebut. Kedua, aspek presisi dari aturan yang dirumuskan dalam perjanjian tersebut. Ketiga, delegasi terhadap pihak ketiga sebagai pengambil keputusan. Berdasarkan tiga aspek itulah maka suatu perjanjian internasional dapat digolongkan sebagai perjanjian internasional yang berkarakter hard law atau soft law. ${ }^{10}$

Abbott et.al mengistilahkan aspek-aspek dalam dua karakteristik tersebut sebagai Concept of Legalization. Dalam menjelaskan dualisme karakteristik tersebut dan aspek-aspek yang penting dalam menganalisis karakteristik tersebut, Abbott et.al menggambarkannya dalam bagan berikut ini:

\section{Gambar 1}

\section{Dimensi Concept of Legalization}
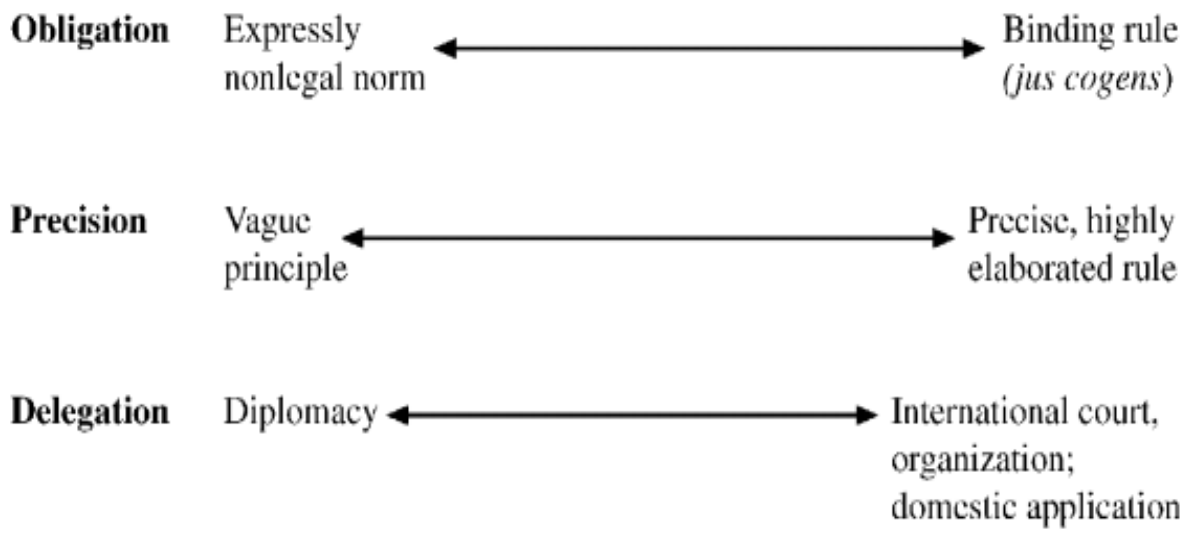

Sumber: Abbot et.al, The Concept of Legalization, International Organization Volume 54, 2000, hlm.404.

${ }^{9}$ Gregory C. Shaffer dan Mark A. Pollack, "Hard versus Soft law in International Security", Boston College Law Review Volume 52, hlm. 1160.

${ }^{10}$ Ibid. 
Berdasarkan bagan tersebut, karakteristik soft law berada di sebelah kiri, sedangkan sebelah kanan menunjukkan karakteristik hard law. Karakteristik soft law dalam perjanjian internasional adalah tidak menyatakan norma hukum, prinsip yang terkandung di dalamnya kabur, dan delegasi wewenang kepada pihak ketiga dalam mengimplementasikannya melalui diplomasi. Sedangkan hard law mengandung aturan yang mengikat, norma yang terkandung di dalamnya dirumuskan secara jelas, dan implementasi aturan tersebut dapat langsung melalui pengadilan internasional, organisasi-organisasi internasional, ataupun implementasi secara langsung di negara masing-masing (misalnya melalui ratifikasi).

Selain tiga aspek tersebut, perbedaan karakter hard law dan soft law dapat dilihat pada pemilihan kata yang digunakan dalam merumuskan perjanjian internasional. Peter H. Sand, sebagaimana dikutip Suparto Wijoyo, menyatakan bahwa tipikal perjanjian internasional berkarakter soft law adalah penggunaan kata "should" daripada "shall". Kata "shall" yang digunakan dalam hard law menunjukkan sebagai kata yang tidak hanya memiliki kewajiban moral, tetapi juga untuk ditaati secara hukum. ${ }^{11}$

Contoh perjanjian internasional yang memiliki karakteristik yang kuat dan dapat dikategorikan sebagai hard law adalah the Agreement on Trade-Related Aspects of Intellectual Property Rights (TRIPs) yang dibentuk melalui Word Trade Organization (WTO). Contoh perjanjian internasional yang memiliki karakteristik soft law adalah The Universal Declaration of Human Rights. Deklarasi tersebut meletakkan kewajiban-kewajiban bagi negara dalam perlindungan hak asasi manusia tetapi sebenarnya secara eksplisit tidak mengikat bagi negara-negara. Contoh lainnya adalah The Nuclear Suppliers Group Guidelines yang merupakan panduan kontrol eksport dan mengatur transfer bahan-bahan nuklir di antara negara-negara. Panduan tersebut disepakati oleh 45 anggota Nuclear Suppliers Group (London Club). Panduan tersebut tidak mengikat secara hukum, tetapi menyatakan pengaturan-pengaturan yang sifatnya

\footnotetext{
${ }^{11}$ Suparto Wijoyo, Op.cit, hlm. 621.
} 
kabur dan mengacu pada perjanjian yang lebih mengikat secara hukum, yaitu Nuclear Nonproliferation Treaty.

Secara sepintas, karakteristik hard law yang lebih dapat diimplementasikan menunjukkan identitasnya sebagai suatu produk hukum. Namun permasalahannya terletak pada karakteristik soft law dalam suatu perjanjian internasional. Bahkan Pierre-Marie Dupuy menyebut soft law sebagai trouble maker dalam sistem hukum karena perjanjian internasional dengan karakter demikian belum dapat dikatakan sebagai hukum atau bahkan sama sekali bukan hukum. Menurut Dupuy, soft law adalah terminologi yang paradoksal untuk mendefinisikan fenomena yang ambigu. Paradoksal karena dari sudut pandang klasik dan umumnya selama ini, suatu aturan hukum selalu dianggap “hard'. Namun menjadi ambigu ketika mengacu pada sulitnya mengidentifikasi akibat hukum yang ditimbulkan aturan hukum yang dianggap sebagai soft law. ${ }^{12}$

Fenomena soft law dalam perkembangan hukum internasional tersebut, menurut Dupuy, disebabkan alasan-alasan yang bersifat sosiologis. Terdapat 3 (tiga) argumentasi yang dapat dikemukakan untuk menjelaskan berkembangnya soft law. Pertama, adanya eksistensi dan perkembangan cabang-cabang jejaring dari institusi yang telah permanen, baik dalam skala dunia maupun regional, semenjak berakhirnya Perang Dunia II. Organisasi-organisasi yang berada di bawah PBB memainkan peranan yang penting dalam hal ini. Organisasiorganisasi ini menawarkan kepada dunia suatu struktur kerjasama yang memungkinkan untuk dipermanenkan. Lebih lanjut lagi adalah perkembangan lembaga-lembaga swadaya masyarakat yang berperan penting dalam hubungan antar pemerintahan di dunia. Peranan lembaga-lembaga tersebut mencakup diplomasi antar negara dan pembentukan opini publik internasional. ${ }^{13}$

Alasan kedua adalah adanya diversifikasi bagian-bagian dari masyarakat dunia. Pada akhir tahun 1950an, munculnya negara-negara yang belum berkembang memunculkan kebutuhan negara-negara tersebut untuk menyesuaikan diri dengan hukum internasional yang telah eksis sebelum negara

${ }^{12}$ Pierre-Marie Dupuy, "Soft law and the International Law of the Environment", Michigan Journal of International Law Volume 12, hlm. 420.

${ }^{13} \mathrm{Ibid}$, hlm. 421. 
tersebut eksis sebagai negara berdaulat. Dalam hubungan negara-negara baru tersebut dengan negara yang lebih dulu ada memunculkan kebutuhan pemanfaatan instrumen-instrumen hukum yang lunak dalam bentuk resolusi atau rekomendasi. ${ }^{14}$

Alasan ketiga adalah alasan terakhir sekaligus yang paling penting untuk menjelaskan fenomena ini. Soft law turut didorong oleh perkembangan ekonomi dunia yang terjadi begitu cepat dan meningkatkan ketergantungan antar negara di dunia. Ketergantungan antar negara tersebut dikombinasikan pula oleh perkembangan bidang baru yang terkait dengan ilmu pengetahuan dan teknologi. Dalam perkembangan ekonomi yang begitu cepat tersebut, bidang ekonomi internasional dan lingkungan hidup adalah bidang yang mengalami pengaruh kuat. Perkembangan tersebut mendorong perlunya instrumen hukum baru yang lebih adaptif dan aplikatif. Dalam konteks inilah muncul produk hukum internasional yang berkarakter soft law dan bidang yang lebih banyak diatur oleh instrumen tersebut adalah bidang ekonomi internasional dan lingkungan hidup. ${ }^{15}$

Terdapat beberapa alasan mengapa negara-negara hingga saat ini masih menganggap perjanjian internasional dengan karakter soft law dibutuhkan. Alasan pertama, negara-negara yang membentuk soft law ingin menghindari resiko yang timbul dari perjanjian internasional tersebut. Oleh karena itu negara-negara pada umumnya memilih resiko yang paling kecil agar dapat menghindari kewajibankewajiban. Jika negara-negara mengikatkan diri pada hard law maka ketika negara-negara tersebut melakukan pelanggaran akan ada sanksi yang mungkin dijatuhkan. Inilah resiko yang ingin dihindari. Hal ini menunjukkan sifat fleksibel dari soft law dan fleksibel hanya bersifat mengarahkan tetapi tidak membebani kewajiban. ${ }^{16}$

Alasan kedua terkait dengan kondisi di tiap-tiap negara agar dapat mengikatkan diri terhadap suatu perjanjian internasional. Dalam konteks negara modern yang bertumpu pada rule of law, pemisahan kekuasaan antara eksekutif

\footnotetext{
${ }^{14}$ Ibid.

${ }^{15}$ Ibid.

16 Andrew T. Guzman dan Timothy L. Meyer, "International Soft law", Journal of Legal Analysis Volume 2 Number 1 Spring 2010, hlm. 176.
} 
dan legislatif menjadikan eksekutif tidak dapat dengan serta merta mengundangkan perjanjian internasionalnya ke dalam hukum nasional. Wewenang tersebut menjadi bagian dari kekuasaan legislatif. Hal tersebut mendorong perlunya proses-proses politik ketika negara ingin menjadikan suatu perjanjian internasional yang disepakatinya memiliki legal binding force. Karakteristik soft law yang lebih lunak dapat mengurangi proses-proses politik yang mungkin dibutuhkan karena kemudian negara tersebut tidak memiliki kewajiban untuk mengadopsi perjanjian internasional tersebut ke dalam hukum nasional. ${ }^{17}$

Dua alasan tersebut adalah alasan yang lebih mula-mula karena dalam perkembangan kajian-kajian terhadap soft law terdapat empat (4) argumentasi baru yang dikemukakan untuk menjawab mengapa negara lebih memilih soft law. 4 argumentasi baru tersebut antara lain: ${ }^{18}$

a. soft law sebagai instrumen koordinasi

Contoh soft law sebagai instrumen koordinasi antar negara dapat dilihat pada Convention for the Unification of Certain Rules Relating to International Carriage by Air atau Konvensi Warsawa. Konvensi ini mengharmonisasikan berbagai macam standar yang terkait dengan perjalanan udara, termasuk di antaranya adalah kepastian standar keamanan. Walaupun negara-negara mungkin memiliki pandangan yang berbeda-beda tentang standar keamanan yang tepat dalam penerbangan, tetapi dianggap penting adanya penyeragaman dalam aspek-aspek tertentu yang bersifat lintas negara. Merupakan sebuah hal yang penting, terkait keselamatan, adanya standar-standar konsisten di negara manapun yang dilewati oleh jalur penerbangan. Inspektur dan mekanik di New York, misalnya, akan mengetahui aspek apa saja yang perlu diperiksa dalam suatu pesawat walaupun pesawat tersebut pangkalan utamanya adalah di Bangkok. Standar lainnya yang lebih sederhana namun memudahkan koordinasi adalah keseragaman pemahaman tentang akronim bandara. Jika pada bagasi penumpang terdapat label JFK, setiap orang akan mengetahui

${ }^{17}$ Ibid, hlm. 177.

${ }^{18}$ Ibid, hlm. 188 - 201. 
bahwa bagasi tersebut ditujukan ke New York karena tidak ada kepanjangan lain dari JFK selain John F. Kennedy International Airport.

b. Teori Loss Avoidance

Argumentasi ini dibangun atas kemungkinan-kemungkinan yang dipikirkan negara untuk dihindari agar tidak mendapat kerugian akibat mengikatkan diri pada suatu perjanjian internasional. Dengan kata lain, ketika negara mengikatkan diri pada suatu perjanjian internasional maka negara tersebut tidak hanya memikirkan apa yang akan didapat ketika melaksanakan perjanjian tersebut tetapi juga biaya atau kerugian yang harus ditanggung ketika negara tersebut melanggarnya.

Dalam konteks perjanjian yang dibuat oleh para pihak dalam satu negara, biaya atau kerugian yang perlu ditanggung jika melanggar perjanjian jauh lebih signifikan daripada akibat yang perlu ditanggung dalam konteks internasional. Hal ini disebabkan sistem peradilan dapat memaksa pihak yang melanggar untuk memberikan ganti rugi kepada pihak yang dirugikan.

Konsekuensi yang harus ditanggung dari pelanggaran perjanjian dalam konteks internasional sungguh berbeda daripada dalam ruang lingkup satu negara. Ganti rugi berupa uang sangat jarang dilakukan. Kenyataannya, pelanggaran sering dikompensasikan melalui mekanisme langsung. Dalam sistem penyelesaian sengketa di WTO, misalnya, terdapat ketentuan yang memungkinkan adanya penalti atau skors terhadap konsesi yang sebelumnya diberikan pada pihak yang melanggar perjanjian (misalnya pelanggaran berupa menaikkan nilai pajak untuk barang-barang tertentu). Namun skorsing terhadap konsesi sebenarnya merugikan bagi kedua belah pihak.

Argumentasi ini serupa dengan argumentasi yang pernah diajukan sebelumnya. Kedudukan soft law yang lunak menyebabkan adanya resiko yang kecil ketika terjadi pelanggaran. Namun dapat terjadi resiko yang harus ditanggung jika mengikatkan diri dalam hard law ternyata lebih kecil daripada keuntungan yang didapat. Jika demikian maka, mengacu pada teori Loss Avoidance, negara dapat juga lebh memilih hard law daripada soft law.

c. Teori Delegasi 
Perjanjian internasional umumnya tidak berlaku untuk jangka waktu tidak terbatas. Dalam merancang perjanjian internasional, negara-negara akan mengantisipasi kebutuhan terhadap suatu aturan hukum untuk berkembang berdasarkan perubahan-perubahan kondisi yang ada. Teori delegasi menyataka bahwa dalam kondisi tertentu soft law adalah cara yang efektif bagi negara untuk mengendalikan ketidakpastian atas masa depan perjanjian internasional yang disepakatinya. Soft law berperan dalam menjawab kebutuhan tersebut karena kemungkinan perubahan-perubahan dalam soft law lebih tinggi daripada hard law.

\section{d. International Common Law Theory}

Teori ini, tidak seperti dua teori sebelumnya, tidak memfokuskan pada negara sebagai aktor utama dalam pembentukan perjanjian internasional. International Common Law adalah produk dari aktor-aktor di luar negara, pada prinsipnya berupa mahkamah internasional dan organisasi internasional dengan wewenang yang terkait dengan aturan hukum internasional. International common law mengacu pada aturan atau standar yang bersifat tidak mengikat yang dikeluarkan oleh institusi-institusi tersebut.

Putusan Mahkamah Internasional bersifat tidak mengikat, kecuali adanya penghormatan oleh pihak-pihak terkait untuk melaksanakan putusan dan adanya fakta-fakta tertentu dalam suatu isu. Karena sifatnya yang demikian maka putusan tersebut dapat dikategorikan pula sebagai soft law. Begitu pula konvensi yang dikeluarkan organisasi internasional dapat juga dikategorikan sebagai soft law karena kekuatan mengikatnya yang lunak terhadap para pihak.

\section{HARMONISASI HARD LAW DI BIDANG LINGKUNGAN HIDUP KE DALAM HUKUM NASIONAL}

Harmonisasi suatu hard law ke dalam hukum nasional ditentukan bilamana perjanjian internasional dinyatakan berlaku dan mengikat bagi negara-negara. Waktu mengikatnya suatu perjanjian internasional biasanya ditentukan dalam perjanjian internasional terkait. Biasanya metode yang ditetapkan dalam 
perjanjian tersebut tetap mengacu pada Konvensi Wina 1969 tentang Hukum Perjanjian Internasional. Setelah suatu negara kemudian telah melalui mekanisme untuk terikat, maka negara tersebut dapat menempuh langkah untuk mengharmonisasikannya ke dalam hukum nasional. Konvensi Wina 1969 mengatur hal tersebut dalam Article 11 (Means of expressing consent to be bound by a treaty). Dalam Article 11 dinyatakan bahwa: "The consent of a state to be bound by a treaty may expressed by signature, exchange of instruments constituting a treaty, ratification, acceptance, approval or accession, or by other means if so agreed."

Berdasarkan Article 11 Konvensi Wina 1969 tersebut, terdapat lima (5) cara untuk menyatakan terikat pada perjanjian internasional, yaitu:

a. penandatanganan;

b. pertukaran instrumen yang melahirkan perjanjian internasional;

c. ratifikasi;

d. akseptasi, persetujuan, atau aksesi;

e. cara-cara lain yang disepakati oleh para pihak.

Walaupun Konvensi Wina 1969 mengatur cara-cara tersebut, tetapi Konvensi Wina 1969 tidak secara jelas menerangkan apa sebenarnya yang dimaksud ratifikasi, akseptasi, persetujuan, dan aksesi. Tidak jelas pula perbedaan di antara istilah-istilah tersebut. Menurut Harjono, kemungkinan besar dicantumkannya cara-cara tersebut karena adanya praktik atau kebiasaan internasional yang menggunakan istilah yang berbeda-beda. Namun dalam praktik pembuatan perjanjian internasional ternyata istilah ratifikasi lebih lazim digunakan daripada istilah akseptasi dan persetujuan. ${ }^{19}$

Anthony Aust, sebagaimana halnya dengan Harjono, juga menyatakan bahwa tidak ada perbedaan yang substansial antara akseptasi atau persetujuan dengan ratifikasi. Saat ini telah menjadi hal yang umum dalam suatu perjanjian internasional multilateral untuk memasukkan syarat ratifikasi dan akseptasi atau persetujuan secara bersamaan. Dalam hal ini ratifikasi dan akseptasi atau

${ }^{19}$ Harjono, Politik Hukum Perjanjian Internasional, Surabaya: Bina Ilmu, 1999, hlm. 130 - 133. 
persetujuan dianggap memiliki kekuatan hukum yang sama dalam aspek mengikatnya suatu perjanjian internasional. ${ }^{20}$

Namun antara ratifikasi dan akseptasi atau persetujuan berbeda dengan aksesi. Aksesi ditujukan bagi negara yang pada waktu perundingan atau penyusunan sebuah perjanjian internasional tidak ikut serta. Namun setelah naskah perjanjian internasional selesai disusun, negara tersebut ingin terikat pada perjanjian internasional yang telah dibuat. Dalam hal inilah suatu negara dinyatakan melakukan aksesi terhadap perjanjian internasional. ${ }^{21}$

Cara lain yang disepakati oleh para pihak menunjukkan fleksibilitas perjanjian internasional dalam menetapkan kekuatan mengikatnya. Bisa saja terjadi suatu perjanjian internasional berkarakter hard law diterima langsung oleh negara, tanpa pembubuhan tanda tangan atau prosedur khusus lainnya, dan langsung memiliki kekuatan mengikat untuk seluruh negara yang menyepakati perjanjian tersebut. Sebagai contoh adalah the Preparatory Commission of the Comprehensive Nuclear Test-Ban Treaty 1996 (CTBT). CTBT diterima oleh negara-negara yang menandatanganinya melalui suatu resolusi dan langsung mengikat sebagai hukum internasional tanpa perlu tindakan hukum lebih lanjut dari negara-negara. ${ }^{22}$

Contoh perjanjian internasional berkarakter hard law yang menetapkan alternatif cara untuk terikat, dengan mengacu pada Konvensi Wina 1969, adalah Protokol Montreal. Hal tersebut dapat dilihat dalam Article 16 (Entry into force) yang menyatakan:

This Protocol shall enter into force on 1 January 1989, provided that at least eleven instruments of ratification, acceptance, approval of the Protocol or accession thereto have been deposited by States or regional economic integration organizations representing at least two-thirds of 1986 estimated global consumption of the controlled substances, and the provisions of paragraph 1 of Article 17 of the Convention have been fulfilled. In the event that these conditions have not been fulfilled by that date, the Protocol shall enter into force on the ninetieth day following the date on which the conditions have been fulfilled.

\footnotetext{
${ }^{20}$ Anthony Aust, Handbook of International Law, Cambridge: Cambridge University Press, 2010, hlm. 61 .

${ }^{21}$ Harjono, Op.cit, hlm. 134.

${ }^{22}$ Anthony Aust, Loc.cit.
} 
Article 16 tersebut menunjukkan bahwa cara ratifikasi, akseptasi, persetujuan dan aksesi menjadi alternatif bagi negara-negara untuk dapat mengikatkan diri ke dalam Protokol Montreal. Dengan mengacu pada Article 16 tersebut, terdapat dua hal menarik dalam aspek pemberlakuan kekuatan mengikat dari protokol tersebut. Pertama, bahwa untuk menyatakan terikat bukan hanya dapat melalui negaranegara tetapi juga dapat melalui organisasi ekonomi regional dengan syarat dan kondisinya diatur pula oleh Protokol Montreal. Kedua, karakter hard law dalam Protokol Montreal nampak dalam kalimat terakhir Article 16 dan dinyatakan bahwa dalam hal kondisi yang perlu dipenuhi (untuk mengikat) tidak tercapai pada tanggal 1 Januari 1989, Protokol Montreal memiliki kekuatan mengikat pada hari kesembilan puluh setelah tanggal dan kondisi-kondisi tersebut telah dipenuhi.

Hal tersebut menunjukkan perjanjian internasional berkarakter hard law cenderung menetapkan cara-cara yang dapat ditempuh oleh negara-negara dalam mengikatkan diri ke dalam hukum nasional. Namun di antara cara-cara tersebut tidak semuanya dapat berkorelasi langsung dengan upaya dalam mengharmonisasikan perjanjian internasional tersebut ke dalam hukum nasional. Cara-cara yang dapat berkorelasi langsung dengan harmonisasi perjanjian internasional tersebut haruslah yang berdampak pada proses legislasi hukum nasional. Karena dengan berdampak secara langsung pada proses legislasi hukum nasional saja suatu perjanjian nasional dapat dikatakan mampu mempengaruhi (atau bahkan merekayasa) instrumen hukum nasional dari suatu negara.

Pasca-pengesahan Undang-Undang Nomor 24 Tahun 2000 tentang Perjanjian Internasional (UU No. 24 Tahun 2000) tidak lagi terdapat kerancuan untuk menentukan instrumen hukum nasional manakah yang digunakan. Setelah berlakunya UU No. 24 Tahun 2000, berbagai bentuk atau cara untuk menyatakan diri terikat dengan suatu suatu perjanjian internasional (ratifikasi, aksesi, akseptasi, persetujuan) dinamakan pengesahan. Istilah "pengesahan" untuk menunjukkan berbagai cara tersebut ditegaskan dalam UU No. 24 Tahun 2000. Pasal 1 Angka 2 UU No. 24 Tahun 2000 menyatakan bahwa: "Pengesahan adalah perbuatan hukum untuk mengikatkan diri pada suatu perjanjian internasional 
dalam bentuk ratifikasi (ratification), aksesi (accession), penerimaan (acceptance) dan penyetujuan (approval)."

Pengesahan suatu perjanjian internasional dapat dilakukan oleh pemerintah jika dipersyaratkan oleh perjanjian internasional tersebut. Pengesahan tersebut dapat dilakukan dengan menggunakan dua bentuk, yaitu undang-undang atau keputusan presiden. Pengesahan dengan menggunakan undang-undang tentu saja membutuhkan persetujuan bersama antara Presiden dan Dewan Perwakilan Rakyat berdasarkan Pasal 20 ayat (2) UUD NRI 1945. Pengesahan dengan keputusan presiden selanjutnya diberitahukan kepada Dewan Perwakilan Rakyat.

Namun khusus untuk bidang lingkungan hidup pengesahan suatu perjanjian internasional tidak dapat dilakukan dengan keputusan presiden. Berdasarkan Pasal 10 UU No. 24 Tahun 2000, perjanjian internasional yang berkenaan dengan bidang lingkungan hidup dilakukan dengan undang-undang. Lengkapnya Pasal 10 menyatakan demikian:

Pengesahan perjanjian internasional dilakukan dengan undang-undang apabila berkenaan dengan:

a. masalah politik, perdamaian, pertahanan, dan keamanan negara;

b. perubahan wilayah atau penetapan batas wilayah negara Republik Indonesia;

c. kedaulatan atau hak berdaulat negara;

d. hak asasi manusia dan lingkungan hidup;

e. pembentukan kaidah hukum baru;

f. pinjaman dan/atau hibah luar negeri.

Dengan demikian, dalam konteks Indonesia, perjanjian internasional berkarakter hard law ke dalam hukum nasional diharmonisasikan dalam peraturan perundang-undangan yang berkarakter hard law. Undang-Undang, dalam sistem peraturan perundang-undangan Indonesia, adalah peraturan perundang-undangan berkarakter hard law atau diistilahkan Gersen dan Posner sebagai hard statutes. Hard law atau hard statutes dalam sistem peraturan perundang-undangan didefinisikan Gersen dan Posner sebagai: "a rule issued by a law-making 
authority that does comply with constitutional and other formalities that are necessary for the rule to be legally binding." 23 Dibandingkan dengan keputusan presiden, undang-undang berkarakter hard law karena kewenangan pembentukannya diatur secara konstitusional maupun oleh undang-undang agar memiliki kekuatan mengikat. Keputusan presiden dapat berkarakter sebagai soft law karena kedudukannya yang dapat ditempatkan sebagai peraturan kebijakan. ${ }^{24}$ Selain itu jika mengacu pada Undang-Undang Nomor 12 Tahun 2011 tentang Pembentukan Peraturan Perundang-undangan, Keputusan Presiden tidak lagi menjadi salah satu bagian dalam hierarki peraturan perundang-undangan di Indonesia. Keputusan Presiden saat ini lebih ditempatkan sebagai beschikking yang sifatnya invidual dan konkrit daripada sebagai regelling yang bersifat umum dan abstrak. Hal ini tentunya akan membuat rancu jika Keputusan Presiden digunakan untuk meratifikasi perjanjian internasional yang sifatnya umum dan abstrak.

Jika mengacu pada konteks Indonesia tersebut, proses harmonisasi perjanjian internasional berkarakter hard law ke dalam hukum nasional dapat digambarkan sebagai berikut:

${ }^{23}$ Jacob E. Gersen dan Eric A. Posner, "Soft law", Stanford Law Review, Forthcoming; University of Chicago, Public Law and Legal Theory Working Paper No. 213, http://ssrn.com/abstract=1113537, diakses pada tanggal 20 Mei 2012.

24 Lihat A. Hamid S. Attamimi, Peranan Keputusan Presiden Republik Indonesia dalam Penyelenggaraan Pemerintahan Negara: Suatu Studi Analisis mengenai Keputusan Presiden yang Berfungsi Pengaturan dalam Kurun Waktu Pelita I - Pelita IV, Disertasi, Fakultas Pascasarjana Universitas Indonesia, 1990. 


\section{Gambar 2}

\section{Harmonisasi Hard law ke dalam Hukum Nasional Indonesia}

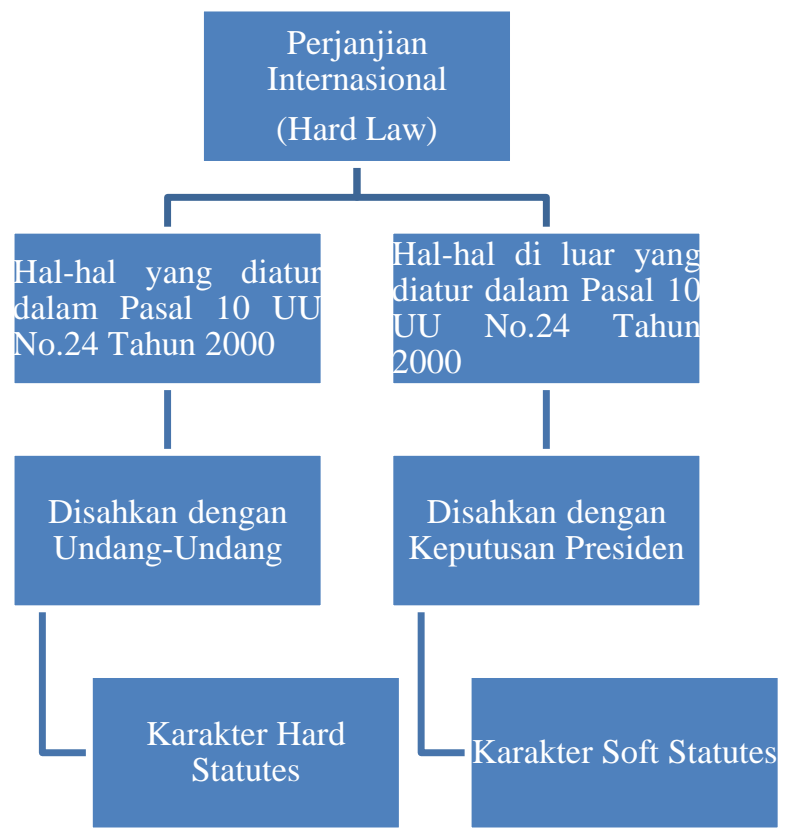

Pascaberlakunya UU No. 24 Tahun 2004, salah satu perjanjian internasional berkarakter hard law yang telah diharmonisasikan ke dalam hukum nasional adalah Protokol Kyoto. Protokol ini telah diratifikasi dalam bentuk undangundang, yaitu Undang-Undang Nomor 17 Tahun 2004 tentang Pengesahan Kyoto Protocol to the United Nations Framework Convention on Climate Change (Protokol Kyoto atas Konvensi Kerangka Kerja Perserikatan Bangsa-Bangsa tentang Perubahan Iklim). Sebelumnya Indonesia juga telah meratifikasi UNFCCC sebagai dasar Protokol Kyoto dengan mengesahkan Undang-Undang Nomor 6 Tahun 1994 tentang Pengesahan United Nations Framework Convention on Climate Change (Konvensi Kerangka Kerja Perserikatan Bangsa-Bangsa tentang Perubahan Iklim). Namun contoh bahwa Amerika Serikat tidak meratifikasi Protokol Kyoto, sebagaimana telah dibahas sebelumnya, menunjukkan bahwa walaupun suatu perjanjian berkarakter hard law tetapi belum tentu memiliki jaminan untuk dapat diharmonisasikan ke dalam seluruh negara.

Contoh-contoh tersebut menunjukkan bahwa harmonisasi perjanjian internasional berkarakter hard law dimulai dari ratifikasi (ratification), aksesi 
(accession), penerimaan (acceptance) dan penyetujuan (approval). Proses tersebut kemudian dapat ditindaklanjuti lewat pengesahan perjanjian internasional tersebut ke dalam hukum nasional.

\section{E. HARMONISASI SOFT LAW DI BIDANG LINGKUNGAN HIDUP KE DALAM HUKUM NASIONAL}

Kesulitan terbesar dalam mengharmonisasikan soft law ke dalam hukum nasional adalah substansi soft law yang cenderung berupa prinsip, kode etik, atau nilai-nilai yang bukan untuk langsung dioperasionalkan sebagai norma. Sebagai contoh adalah Deklarasi Rio yang terdiri atas 27 Prinsip. Jika dibandingkan, rumusan prinsip-prinsip tersebut berbeda dengan rumusan aturan-aturan dalam Protokol Montreal yang dapat langsung diratifikasi ke dalam hukum nasional.

Oleh karena itu, pendekatan yang digunakan dalam mengharmonisasikan soft law ke dalam hukum nasional bukanlah melalui instrumen legislasi nasional. Merupakan suatu hal yang percuma meratifikasi suatu perjanjian internasional yang rumusannya adalah prinsip, asas, nilai ke dalam bentuk Undang-Undang yang rumusannya mengandung norma perilaku atau norma kewenangan. Hal yang terpenting adalah bagaimana prinsip dan nilai-nilai tersebut dapat ditransformasikan menjadi peraturan perundang-undangan dalam bentuk norma perilaku atau norma kewenangan walaupun mungkin tidak dengan tegas menyatakan merujuk pada soft law yang terkait.

Repetisi merupakan faktor yang menentukan dalam mengharmonisasikan soft law ke dalam hukum nasional. Lluis Paradell-Trius menyatakan bahwa: ${ }^{25}$

It can be observed, however, that repetition is an important factor in this process. The international bodies and instruments referred to above should be viewed in this light. Cross-references between documents and institutions, the recalling of principles enshrined in different instruments, the persistent and recurrent invocation of the same standards, the convergence, reiteration and concurrence of resolutions and declarations, all gradually contribute to develop and establish principles.

\footnotetext{
${ }^{25}$ Lluis Paradell-Trius, "Principles of International Environmental Law: an Overview", Review of European Community\& International Environmental Law Volume 9 Issue 2, hlm. 97
} 
Berdasarkan pendapat Paradell-Trius tersebut, repetisi sebagai faktor penentu dapat diimplementasikan dalam bentuk saling merujuk antar dokumen dan institusi. Mengingatkan kembali akan prinsip-prinsip atau nilai-nilai yang sudah dibangun melalui seruan atau himbauan, walaupun terlihat sepele, menjadi penting untuk memgembangkan prinsip-prinsip tersebut secara bertahap. Bisa saja terjadi kemudian suatu negara menggunakan prinsip-prinsip tersebut dalam peraturan perundang-undangan yang bersifat sektoral.

Sependapat dengan Paradell-Trius, Dupuy juga menempatkan repetisi sebagai faktor paling penting dalam harmonisasi soft law, khususnya di bidang lingkungan hidup. Saling merujuk antar institusi juga menjadi contoh pola harmonisasi soft law yang diusulkan oleh Dupuy. Hal tersebut semata untuk mengembangkan dan menciptakan pemahaman umum terhadap suatu prinsip dalam ruang lingkup internasional. Sebagai hasil dari repetisi tersebut, bisa saja terjadi prinsip yang dua puluh tahun sebelumnya ditentang oleh suatu negara kemudian justru menjadi prinsip utama dalam kebijakan negara tersebut. ${ }^{26}$

Harmonisasi soft law ke hukum nasional melalui repetisi diilustrasikan Dupuy dengan empat contoh. Contoh pertama yang dikemukakan Dupuy adalah harmonisasi prinsip informasi dan konsultasi dalam hukum internasional di bidang lingkungan hidup. Prinsip ini memberikan kewajiban kepada setiap negara untuk menginformasikan dan mengkonsultasikan kepada negara lainnya sebelum melakukan aktivitas yang dapat menyebabkan pencemaran lintas perbatasan negara. Dengan demikian negara yang berpotensi menyebabkan pencemaran tersebut dapat mempertimbangkan berbagai aspek sebelum melakukan kegiatan tersebut.

Prinsip tersebut telah ditegaskan selama kurang lebih dua puluh tahun oleh organisasi-organisasi yang berbeda. Prinsip tersebut dapat ditemukan dalam banyak rekomendasi dan resolusi. Misalnya adalah UNEP Draft Principles of Conduct on Shared Natural Resources; Resolusi Majelis Umum PBB Nomor 3129 (XXVIII) pada bulan Desember 1973 dan Resousi Majelis Umum PBB Nomor 3281 (the Charter of Economic Rights and Duties of States); Recomendasi

${ }^{26}$ Pierre-Marie Dupuy, Op.cit, hlm. 424. 
Dewan OECD tentang Pencemaran Lintas Batas dan Implementasi dari Hak atas Akses yang Sama dan Non Diskriminasi dalam hubungannya dengan Pencemaran Lintas Batas.

Jika dikaitkan dengan prinsip lainnya, prinsip informasi dan konsultasi tersebut terkait dengan prinsip state responsibility di bidang pencemaran lintas batas. Jika suatu negara kemudian tidak menginformasikan dan mengkonsultasikan kegiatannya yang dapat menimbulkan pencemaran lintas batas, maka negara tersebut bertanggung jawab atas pencemaran yang merugikan negara lain tersebut.

Prinsip tersebut sebenarnya telah diadopsi dalam Undang-Undang Nomor 23 Tahun 1997 tentang Pengelolaan Lingkungan Hidup (UU No. 23 Tahun 1997) sebelum diganti dengan Undang-Undang Nomor 32 Tahun 2009 tentang Perlindungan dan Pengelolaan Lingkungan Hidup (UU No. 32 Tahun 2009). Namun prinsip tanggung jawab negara tersebut tidak diharmonisasikan dalam bentuk norma perilaku, tetapi sekedar mendeskripsikan asas-asas yang dianut dalam UU No.23 Tahun 1997. Hal tersebut dapat dilihat dalam Pasal 3 UU No. 23 Tahun 1997 yang menyatakan sebagai berikut:

Pengelolaan lingkungan hidup yang diselenggarakan dengan asas tanggung jawab negara, asas berkelanjutan, dan asas manfaat bertujuan untuk mewujudkan pembangunan berkelanjutan yang berwawasan lingkungan hidup dalam rangka pembangunan manusia Indonesia seutuhnya dan pembangunan masyarakat Indonesia seluruhnya yang beriman dan bertaqwa kepada Tuhan Yang Maha Esa.

Rumusan Pasal 3 tersebut dapat dipahami melalui Penjelasan Pasal 3 UU No.23 Tahun 1997:

Berdasarkan asas tanggung jawab negara, di satu sisi, negara menjamin bahwa pemanfaatan sumber daya alam akan memberikan manfaat yang sebesar-besarnya bagi kesejahteraan dan mutu hidup rakyat, baik generasi masa kini maupun generasi masa depan. Di lain sisi, negara mencegah dilakukannya kegiatan pemanfaatan sumber daya alam dalam wilayah yurisdiksinya yang menimbulkan kerugian terhadap wilayah yurisdiksi negara lain, serta melindungi negara terhadap dampak kegiatan di luar wilayah negara. Asas keberlanjutan mengandung makna setiap orang memikul kewajibannya dan tanggung jawab terhadap generasi mendatang, dan terhadap sesamanya dalam satu generasi. Untuk terlaksananya kewajiban 
dan tanggung jawab tersebut, maka kemampuan lingkungan hidup, harus dilestarikan. Terlestarikannya kemampuan lingkungan hidup menjadi tumpuan terlanjutkannya pembangunan.

Berdasarkan Penjelasan Pasal 3 tersebut tampak jelas bahwa negara Indonesia pada prinsipnya mencegah dilakukannya kegiatan pemanfaatan sumber daya alam dalam wilayah Indonesia yang menimbulkan kerugian bagi negara lain. Prinsip untuk tidak mengganggu negara lain melalui pencemaran, yang kemudian menderivasikan prinsip informasi dan konsultasi, dengan demikian dianut dalam Pasal 3. Namun suatu prinsip jika diadopsi secara langsung ke dalam peraturan perundang-undangan sebagai suatu prinsip pula, tanpa ditransformasikan menjadi norma perilaku, tentunya tidak akan menjadi norma yang dapat dioperasionalkan. Prinsip tersebut akan sekedar menjadi asas yang tercantum dalam undang-undang.

Dalam kasus kebakaran hutan di Indonesia (khususnya di Sumatera dan Kalimantan) tahun 1997, yang kemudian mencemari udara negara-negara tetangga di Asia Tenggara, kebijakan penanganan pembakaran hutan bukan didasarkan atas kewenangan membuat kebijakan dalam menangani pencemaran lintas batas. Kebijakan tersebut dibuat atas dasar diskresi tanpa berdasarkan norma kewenangan yang lahir dari prinsip tanggung jawab negara. Untuk menangani pencemaran lintas batas tersebut pemerintah kemudian membentuk peraturan kebijakan berupa Keputusan menteri Negara Lingkungan Hidup Nomor KEP40/MENLH/09/1998 tentang Pembentukan Tim Koordinasi Nasional Pengendalian Kebakaran Hutan.

Prinsip tanggung jawab negara kemudian dilanjutkan dalam UU No. 32 Tahun 2009. Prinsip dan asas dalam perlindungan dan pengelolaan lingkungan hidup diatur dalam Pasal 2 UU No. 32 Tahun 2009. Dalam Pasal 2 dinyatakan bahwa perlindungan dan pengelolaan lingkungan hidup dilaksanakan berdasarkan asas:
a. tanggung jawab negara;
b. kelestarian dan keberlanjutan;
c. keserasian dan keseimbangan;
d. keterpaduan; 
e. manfaat;

f. kehati-hatian;

g. keadilan;

h. ekoregion;

i. keanekaragaman hayati;

j. pencemar membayar;

k. partisipatif;

1. kearifan lokal;

m. tata kelola pemerintahan yang baik; dan

n. otonomi daerah.

Namun terjadi perubahan ruang lingkup dan harmonisasi prinsip tanggung jawab negara jika dibandingkan dengan UU No. 23 Tahun 1997. Penjelasan Pasal 2 menjelaskan tiga aspek dalam prinsip tanggung jawab negara. Tiga aspek tersebut antara lain:

a. negara menjamin pemanfaatan sumber daya alam akan memberikan manfaat yang sebesar-besarnya bagi kesejahteraan dan mutu hidup rakyat, baik generasi masa kini maupun generasi masa depan;

b. negara menjamin hak warga negara atas lingkungan hidup yang baik dan sehat;

c. negara mencegah dilakukannya kegiatan pemanfaatan sumber daya alam yang menimbulkan pencemaran dan/atau kerusakan lingkungan hidup.

Berdasarkan Penjelasan tersebut, tanggung jawab negara tidak lagi disebutkan secara spesifik untuk mencegah pencemaran lintas negara. Namun prinsip tersebut kemudian dirumuskan lebih universal bahwa negara mencegah kegiatan pemanfaatan sumber daya alam yang menimbulkan pencemaran dan/atau kerusakan lingkungan hidup. Pencemaran dan kerusakan lingkungan hidup seharusnya diinterpretasikan bukan hanya yang berdampak pada yurisdiksi Indonesia tetapi juga yurisdiksi negara lain. 
Perubahan yang signifikan dalam harmonisasi prinsip tersebut ke dalam undang-undang adalah dengan tidak hanya mencantumkan rumusan prinsip saja tetapi juga mentransformasikannya ke dalam rumusan norma kewenangan. Transformasi prinsip tanggung jawab negara ke dalam norma kewenangan dapat dilihat dalam Pasal 63 ayat (1) huruf m. Dalam pasal tersebut dinyatakan bahwa dalam perlindungan dan pengelolaan lingkungan hidup, Pemerintah bertugas dan berwenang menetapkan dan melaksanakan kebijakan mengenai pencemaran dan/atau kerusakan lingkungan hidup lintas batas negara. Dengan ditransformasikannya prinsip atau asas menjadi norma kewenangan, maka dampak dari soft law ke dalam hukum nasional akan lebih terasa jika dibandingkan dengan sekedar memuat asas atau prinsip saja.

Prinsip lain yang berkembang dalam soft law yang kemudian diharmonisasikan melalui repetisi adalah polluter pays-principle atau prinsip pencemar membayar. Prinsip ini lebih dikenal lahir melalui Deklarasi Rio. Namun sesungguhnya prinsip ini telah dikenalkan beberapa tahun sebelumnya melalui instrumen-instrumen soft law dan diulang-ulang juga dalam bentuk soft law.

Instrumen soft law yang pertama kali mengenalkan prinsip pencemar membayar adalah OECD Council Recommendation on Guiding Principles Concerning the International Economic Aspects of Environmental Policies tahun 1972. Berdasarkan dokumen ini, pencemar seharusnya mengalokasikan biaya bagi upaya pencegahan dan kontrol agar negara dapat mendorong penggunaan sumber daya alam secara rasional. Prinsip ini diharapkan tidak mengakibatkan distorsi dalam perdagangan internasional dan investasi. Dengan kata lain, biaya yang harus dibayarkan tersebut seharusnya mencerminkan biaya dari barang atau jasa yang menyebabkan polusi karena adanya produksi dan/atau konsumsi dari barang atau jasa tersebut. ${ }^{27}$ Annex I Guiding Principles Concerning the International Economic Aspects of Environmental Policies menyatakan sebagai berikut:

The principle to be used for allocating costs of pollution prevention and control measures to encourage rational use of scarce environmental resources and to avoid distortions in international trade and investment is the

27 Philippe Sands, Principles of International Environmental Law $2^{\text {nd }}$ Edition, Cambridge: Cambridge University Press, 2003, hlm. 281. 
Manuel Simbolon, Perjanjian Internasional sebagai Instrumen ...

so-called 'Polluter Pays principle'. This principle means that the polluter should bear the expenses of carrying out the above mentioned measures decided by public authorities to ensure that the environment is in an acceptable state. In other words, the cost of these measures should be reflected in the costs of goods and services which cause pollution in production and/or consumption. Such measures should not be accompanied by subsidies that would create significant distortions in international trade and investment.

Prinsip tersebut kemudian dikenalkan kembali (repetisi) dalam International Convention on Oil Pollution Preparedness, Response and Cooperation yang diselenggarakan oleh International Maritime Organization pada tahun 1990. Konvensi tersebut menyatakan bahwa prinsip pencemar membayar merupakan salah satu prinsip umum dalam hukum lingkungan internasional. Begitu pula Article 174 (2) Treaty Establishing the European Union (EC Treaty), menyatakan bahwa:

Union policy on the environment shall aim at a high level of protection taking into account the diversity of situations in the various regions of the Union. It shall be based on the precautionary principle and on the principles that preventive action should be taken, that environmental damage should as a priority be rectified at source and that the polluter should pay.

Namun prinsip pencemar membayar lebih dikenal dalam Prinsip 16 Deklarasi Rio. Berdasarkan Deklarasi tersebut, pemerintah seharusnya berusaha untuk mengupayakan adanya internalisasi biaya lingkungan dan penggunaan instrumen ekonomi. Berdasarkan kepentingan publik, pencemar seharusnya menanggung beban biaya akibat polusi yang ditimbulkannya. Serupa dengan prinsip pencemar membayar dalam OECD Council Recommendation on Guiding Principles Concerning the International Economic Aspects of Environmental Policies, pelaksanaan prinsip ini diharapkan tidak menganggu perdagangan internasional dan investasi.

Melalui repetisi-repetisi itulah, prinsip pencemar membayar kemudian diharmonisasikan ke dalam peraturan perundang-undangan di Indonesia. UU No.23 Tahun 1997 tidak pernah mengatur adanya prinsip pencemar membayar. Namun Penjelasan Pasal 34 ayat (1) menyatakan bahwa norma dalam Pasal 34 
ayat (1) merupakan realisasi asas pencemar membayar. Padahal ketentuan Pasal 34 ayat (1) sangatlah berbeda dengan yang dimaksud dalam prinsip pencemar membayar. Pasal 34 ayat (1) menyatakan: "Setiap perbuatan melanggar hukum berupa pencemaran dan/atau perusakan lingkungan hidup yang menimbulkan kerugian pada orang lain atau lingkungan hidup, mewajibkan penanggung jawab usaha dan/atau kegiatan untuk membayar ganti rugi dan/atau melakukan tindakan tertentu."

Berdasarkan rumusan tersebut, prinsip pencemar membayar hanya dimaknai sebagai instrumen untuk menuntut pertanggungjawaban hukum dalam aspek keperdataan. Padahal prinsip pencemar membayar memiliki aspek yang luas. Sebagai instrumen internalisasi biaya lingkungan, prinsip ini digunakan untuk membebankan biaya bagi pihak yang berpotensial untuk mencemari lingkungan. Biaya yang dibayarkan pihak yang berpotensial mencemari tersebut kemudian digunakan oleh pemerintah untuk memulihkan kondisi lingkungan sekitarnya. ${ }^{28}$

Substansi UU No. 32 Tahun 2009 sebagai pengganti UU No. 23 Tahun 1997 kemudian mengalami perubahan dalam ruang lingkup prinsip pencemar membayar. Prinsip pencemar membayar sebagai salah satu prinsip yang melandasi UU No. 32 Tahun 2009 dicantumkan dalam Pasal 2. Prinsip pencemar membayar sebagai instrumen pertanggungjawaban hukum jika terjadi sengketa, sebagaimana diatur dalam Pasal 34 ayat (1) UU No. 23 Tahun 1997, juga diatur dalam Pasal 87 ayat (1). Berdasarkan Penjelasan Pasal 87 ayat (1), selain diharuskan membayar ganti rugi, pencemar dan/atau perusak lingkungan hidup dapat pula dibebani oleh hakim untuk melakukan tindakan hukum tertentu, misalnya perintah untuk:

a. memasang atau memperbaiki unit pengolahan limbah sehingga limbah sesuai dengan baku mutu lingkungan hidup yang ditentukan;

b. memulihkan fungsi lingkungan hidup; dan/atau

c. menghilangkan atau memusnahkan penyebab timbulnya pencemaran dan/atau perusakan lingkungan hidup.

\footnotetext{
${ }^{28}$ Muhamad Muhdar, "Eksistensi Polluter Pays Principle dalam Pengaturan Hukum Lingkungan di Indonesia, Mimbar Hukum Volume 21 Nomor 1 Februari 2009, hlm. 78.
} 
Selain sebagai instrumen penegakan hukum, prinsip pencemar membayar dalam UU No. 32 Tahun 2009 juga mulai diberlakukan sebagai instrumen internalisasi biaya lingkungan. Ketentuan untuk mengimplementasikan prinsip tersebut terdapat dalam Pasal 54 ayat (1) dan (2):

(1)Setiap orang yang melakukan pencemaran dan/atau perusakan lingkungan hidup wajib melakukan pemulihan fungsi lingkungan hidup.

(2)Pemulihan fungsi lingkungan hidup sebagaimana dimaksud pada ayat (1) dilakukan dengan tahapan:
A. penghentian sumber pencemaran dan pembersihan unsur pencemar;
B. remediasi;
C. rehabilitasi;
D. restorasi; dan/atau
E. cara lain yang sesuai dengan perkembangan ilmu pengetahuan dan teknologi.

Untuk melaksanakan pemulihan fungsi lingkungan hidup tersebut, pemegang izin lingkungan wajib menyediakan dana penjaminan. Dana penjaminan tersebut disimpan di bank pemerintah yang ditunjuk oleh Menteri, gubernur, atau bupati/walikota sesuai dengan kewenangannya. ${ }^{29}$ Dengan demikian prinsip pencemar membayar diharmonisasikan ke dalam UU No.32 Tahun 2009 bukan hanya berupa pencantuman prinsip tetapi juga mentransformasikannya ke dalam norma kewenangan dalam ruang lingkup yang lebih luas daripada dalam UU No.23 Tahun 1997.

Contoh-contoh harmonisasi prinsip hukum lingkungan internasional dalam soft law tersebut menunjukkan bahwa harmonisasi soft law ke dalam hukum nasional ditentukan oleh repetisi prinsip-prinsip tersebut dalam beberapa instrumen soft law. Berbeda dengan harmonisasi hard law, harmonisasi soft law ke dalam hukum nasional tidak melalui proses ratifikasi keseluruhan suatu

${ }^{29}$ Pasal 55 ayat (1) dan (2) UU No. 32 Tahun 2009. 
perjanjian internasional. Harmonisasi tersebut terjadi secara bertahap dengan diintrodusir ke dalam peraturan perundang-undangan yang terkait, lebih khususnya dalam peraturan perundang-undangan yang mengatur tentang lingkungan hidup.

\section{F. Penutup}

Harmonisasi hard law ke dalam hukum nasional ditentukan oleh bagaimana hard law tersebut diintrodusir ke dalam hukum nasional melalui proses legislasi atau disebut pula ratifikasi. Dalam konteks Indonesia, melalui ratifikasi, perjanjian internasional di bidang lingkungan hidup yang berkarakter hard law disahkan sebagai peraturan perundang-undangan yang mengikat ke dalam melalui UndangUndang atau Keputusan Presiden. Namun ketika hard law tersebut diratifikasi melalui Keputusan Presiden, hard law tersebut telah ditransformasikan menjadi soft statute di dalam hukum nasional. Sedangkan harmonisasi soft law ke dalam hukum nasional ditentukan oleh repetisi prinsip-prinsip yang ada di dalam soft law. Keseluruhan prinsip dalam suatu soft law (misalnya deklarasi) tidak diintrodusir dalam suatu peraturan perundang-undangan tersendiri seperti hard law, tetapi diintrodusir ke dalam peraturan perundang-undangan yang terkait dengan prinsip tersebut.

Oleh karena itu perlu ditinjau kembali mekanisme ratifikasi hard law dengan menggunakan Keputusan Presiden karena sifat Keputusan Presiden yang lebih sesuai untuk penetapan (beschikking). Sedangkan perjanjian internasional bersifat mengatur (regelling) dan rumusannya umum-abstrak. Jika dipaksakan karakternya sebagai peraturan maka Keputusan Presiden dikategorikan sebagai soft statute karena berdasarkan UU No. 12 Tahun 2011 tidak dikategorikan sebagai salah satu jenis peraturan perundang-undangan. Hal ini tentu saja bertentangan dengan karakter perjanjian internasional yang diratifikasi, yaitu berkarakter hard law.

Harmonisasi prinsip-prinsip dalam soft law ke dalam hukum nasional seharusnya tidak sekedar dengan mencantumkan asas ke dalam peraturan perundang-undangan karena prinsip-prinsip dalam soft law tersebut menjadi tidak 
Manuel Simbolon, Perjanjian Internasional sebagai Instrumen ...

operasional. Harmonisasi prinsip-prinsip tersebut seharusnya dengan mentransformasikannya ke dalam norma perilaku atau norma kewenangan.

\section{DAFTAR PUSTAKA}

Drumbl, Mark, "Actors and Law-Making in International Environmental Law", Washington \& Lee Public Legal Studies Research Paper Series, http://ssrn.com/abstract=1022363, diakses pada tanggal 25 April 2012.

Dupuy, Pierre-Marie, "Soft law and the International Law of the Environment", Michigan Journal of International Law Volume 12.

Friedman, Thomas L., 2006, The World is Flat: Sejarah Singkat Abad ke-21, Cet. I, Jakarta: Dian Rakyat.

Gersen, Jacob E. dan Eric A. Posner, "Soft Law", Stanford Law Review, Forthcoming; University of Chicago, Public Law and Legal Theory Working Paper No. 213, http://ssrn.com/abstract=1113537, diakses pada tanggal 20 Mei 2012.

Giddens, Anthony, 1999, The Third Way: The Renewal of Social Democracy, Jalan Ketiga: Pembaruan Demokrasi Sosial, Terjemahan oleh Ketut Arya Mahardika, Jakarta: Gramedia Pustaka Utama.

Guzman, Andrew T. dan Timothy L. Meyer, 2010, "International Soft law", Journal of Legal Analysis Volume 2 Number 1 Spring.

Harjono, 1999, Politik Hukum Perjanjian Internasional, Surabaya: Bina Ilmu.

Muhdar, Muhamad, 2009, "Eksistensi Polluter Pays Principle dalam Pengaturan Hukum Lingkungan di Indonesia”, Mimbar Hukum Volume 21, Nomor 1, Februari.

Paradell-Trius, Lluis, "Principles of International Environmental Law: an Overview", Review of European Community\& International Environmental Law Volume 9 Issue 2.

Sands, Philippe, 2003, Principles of International Environmental Law $2^{\text {nd }}$ Edition, Cambridge: Cambridge University Press.

Schrijver, Nico, 1997, Sovereignty over Natural Resources, Cambridge: Cambridge University Press. 
Shaffer, Gregory C. dan Mark A. Pollack, "Hard versus Soft law in International Security", Boston College Law Review Volume 52.

Stratton, Jane, 2009, International Environmental Law, dalam International Law, ed.Cathy Hammer, Sydney: Legal Information Access Centre.

Wijoyo, Suparto, 2005, Refleksi Matarantai Pengaturan Hukum Pengelolaan Lingkungan secara Terpadu, Surabaya: Airlangga University Press. 